\title{
Family farming products on menus in school feeding: a partnership for promoting healthy eating
}

\author{
Produtos da agricultura familiar nos cardápios da alimentação escolar: \\ uma parceria para promoção da alimentação saudável
}

\author{
Hélida Ventura Barbosa Gonçalves ${ }^{\mathrm{I}}$ Diogo Thimoteo da Cunha \\ Elke Stedefeldt ${ }^{\text {II }}$ Veridiana Vera de Rosso ${ }^{\text {III }}$
}

\section{ABSTRACT}

The aim of this study was to characterize the process of buying Family Farming (FF) food for the Brazilian School Feeding Program (BSFP) and compare the quality of menus served to the schoolchildren before and after the implementation of Law n. 11,947/09. This is an observational cross-sectional study developed with application of semi-structured questionnaire and evaluating menus. Eighty-two cities from São Paulo and Rio de Janeiro in Brazil participated of the study. Of these cities reported, $74.1 \%$ performed the purchase of products of FF for BSFP. The lack of interest of farmers and the deficient hygienic and sanitary conditions were the main difficulties reported. The quality of the menus offered to the schoolchildren improved significantly after the implementation of FF purchases. The partnership between FF and BSFP can contribute greatly to the development of healthy eating habits, not only by offering better nutritional quality menus, but also by implementing of nutritional education activities guided by the sustainable production and consumption of food.

Key words: school feeding, family farming, healthy eating, school food and nutrition program.

\section{RESUMO}

$O$ objetivo do estudo foi caracterizar o processo de compra de alimentos da Agricultura Familiar (AF) para a Alimentação Escolar (AE) e comparar a qualidade dos cardápios servidos aos escolares antes e após a implantação da lei $n$. 11.947/09. Trata-se de um estudo transversal realizado com aplicação de questionário semiestruturado e avaliação de cardápios. Participaram da pesquisa 82 municípios, dos estados de São Paulo e Rio de Janeiro. Destes, 74,1\% informaram realizar a compra de produtos da AF para a AE. O desinteresse dos agricultores familiares e as condições higiênico-sanitárias deficientes foram as principais dificuldades reportadas pelos municípios para a efetivação das compras da AF. A qualidade dos cardápios oferecidos aos escolares melhorou significativamente após a implementação das compras da AF. A parceria entre a $A F$ e a $A E$ pode contribuir sobremaneira para o desenvolvimento de hábitos alimentares saudáveis, não só pelo oferecimento de cardápios de melhor qualidade nutricional, mas pela execução de atividades de educação nutricional pautadas na produção e consumo sustentável dos alimentos.

Palavras-chave: alimentação escolar, agricultura familiar, alimentação saudável, programa de alimentação e nutrição escolar.

\section{INTRODUCTION}

According to the regulations of the Brazilian government, school feeding aims to use of healthy and adequate food in order to meet the nutritional references, dietary habits, food culture and traditions, contributing to practice good living habits. A student well fed has a higher educational attainment, with the balance needed for their growth and development (BRAZIL, 2009; MATIHARA et al., 2010; NEITZKE et al., 2012).

The school feeding menus, under the responsibility of cities and states, must be designed to meet $30-70 \%$ of the daily nutritional needs, according to the stay in the school environment (BRAZIL, 2013). At school, adequate quality and quanty in food is essential to ensure the growth and development

\footnotetext{
${ }^{\mathrm{I}}$ Grupo de Estudos de Qualidade de Alimentos (GeQual), Programa de Pós-graduação Interdisciplinar em Ciências da Saúde, Universidade Federal de São Paulo (Unifesp), São Paulo, SP, Brasil



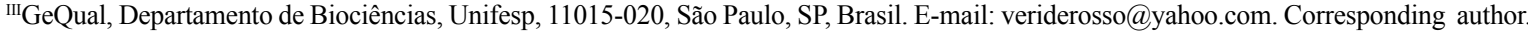
Received 02.15.15 Approved 05.15.15 Returned by the author 07.25.15 CR-2015-0214.R1
} 
children as it provides energy and nutrients needed for good performance of its functions and the maintenance of health (NEITZKE et al., 2012).

The enactment Law n. 11,947/2009 provided advances to the BSFP, especially with regard to quality of the menus and sustainable regional development, by encouraging purchase of food at the local level, with the participation of farmers family and rural family entrepreneurs. Based on the law, employment of at least $30 \%$ of the funds granted by Brazilian government (specifically, the National Fund for Education Development FNDE in Portuguese) became mandatory for buying food directly from family farmers (BRAZIL, 2009). At the national level this value corresponded to $\mathrm{R} \$$ 1,05 billion in 2013 (FNDE, 2014).

Although the purchase of family farming products is a step forward in relation to the transfer of income and strengthening of the local economy, few studies have been published so far, and they are restricted to the purchase panorama between family farmers and school feeding programs in regional and national ambit (VILLAR et al., 2013; SARAIVA et al., 2013). The impact of the acquisition of these products in school meals, specifically the quality of the menus offered to schoolchildren, has not been described in scientific literature.

Facing this context, the objectives of this study were: 1) to characterize the process of buying food from family farming for school feeding in a group of cities of São Paulo and Rio de Janeiro in Brazil and; 2) compare the quality of menus served in school meals before and after the implementation of Law n. 11,947/09.

\section{MATERIAL AND METHODS}

This study was cross-sectional and was developed from January 2012 to November 2013. Brazilian cities belonging to the states of São Paulo and Rio de Janeiro, located in the southeastern region of Brazil were involved in it. It was used simple random sampling, considering the totality of cities of the two states (737), being 654 cities of São Paulo added to 92 of Rio de Janeiro. A pilot study was conducted with 23 cities to calculate the sample size and test questionnaire understanding. Sample size was calculated considering $95 \%$ of global confidence interval and 10\% sampling error. The response obtained for this calculation proved to be necessary for the implementation of the questionnaire in at least 79 cities in both states.

A semi-structured questionnaire consisting of 22 questions about the buying process from family farming was developed taking as parameters the Law n. 11,947/09 and the Resolution CD/FNDE n.26/2013 (BRAZIL, 2009; BRAZIL 2013). The questionnaire was sent by e-mails to the participating cities in the study, after prior telephone contact with nutritionists responsible for the school feeding. It was also requested examples of weekly menus served to elementary schoolchildren who study part-time (four hours and half stay in school). The menus were classified as pre- and post-start buying food from family farming. It was only requested a copy of the current weekly menu from the cities that did not perform the purchase through family farming.

The menus were qualitatively analyzed considering the presence of food by groups according to the method proposed by DOMENE et al. (2011). This method considers that the occurrence of food for groups can be used as menu quality marker obtaining a Quality Index for School Feeding Menu (QISFM).

The QISFM scores of each menu were established and grouped into five categories: percentile 1: bad (QISFM 0 to 2.1); percentile 2: poor (QISFM 2.2 to 2.6); percentile 3: regular (QISFM 2.7 to 2.9); percentile 4: good (QISFM 3.0 to 3.4); percentile 5: great (QISFM above 3.5). Categories defined as bad and poor were considered unsatisfactory conditions.

To check the effect of Law n. 11,947/09 on food, the differences between the scores of QISFM of the menu offered anteriorly and posteriorly the family farming purchase were determined.

Regarding the statistical analysis, it was performed the Goodness-to-fit test Kolmogorov Smirnov for the quantitative variables, checking if the distributions of variables were homogeneous. It was verified the existence of homoscedasticity (equal variances) by the Levene test. In the comparison and magnitude of the difference between the QISFM menus before and after beginning the family farming purchase it was used the t-Student test for related samples. In all tests it was considered the significant value of $\mathrm{P}<0.05$ and it was used the SPSS v.15.0 software.

\section{RESULTS AND DISCUSSION}

In this study 82 cities participated in the survey, with 63 belonging to the state of São Paulo ( $9.8 \%$ of all cities in the state) and 19 to the state of Rio de Janeiro (20.7\% of the cities in the state). Prior to the publication of the Law n. 11,947/09, $24.4 \%(n=20)$ of the cities studied products were purchased from family farmers; $35 \%$ of them $(n=7)$ reported buying through normal bidding process and $20 \%(n=4)$ through Food Acquisition Program. Of

Ciência Rural, v.45, n.12, dez, 2015. 
the cities studied $24.4 \%(n=20)$ did not purchase any products from family farmers for school program by the end of 2013, and $22.2 \%(n=18)$ reported buying up the percentage of purchasing established by law. Of these $22.2 \%$, four cities acquired over $50 \%$. It is noteworthy that 2012 and 2013 were the third and fourth years of compulsory law, and that most cities started this purchase process, although there is a significant noncompliance of the law.

In 2012, 19\% of the cities of São Paulo bought food through FF, employing more than $30 \%$ of the resource transferred by the Brazilian government (MINISTÉRIO DO DESENVOLVIMENTO AGRÁRIO, 2014). In a previous study nationwide was identified that eight of the 18 cities analyzed also acquired over $30 \%$ of the resource (TOYOYOSHI et al., 2013). Considering only the Brazilian southeast region, the purchase over $30 \%$ was reported by $42.4 \%$ of cities (SARAIVA et al., 2013).

It was observed that the law was being fulfilled in $47 \%$ of cities studied between June and August 2011 in São Paulo (VILLAR et al., 2013). Despite the obligation of purchase was fixed in January 2010 , it is observed that this implementation was achieved gradually in the early years and may be due to an adaptation to the legislation or even knowledge of farmers for later incorporation of the activity.

In the present study was observed that 2010 and 2011 were years of the beginning of the purchasing process for $67.1 \%$ of the cities. It was also noted that after this period there has been a deceleration in the number of cities that started the purchasing process. In a study based on literature review and official data of Brazilian government, $47.4 \%$ of Brazilian cities have reported acquiring FF for the NSFP in 2010 (SARAIVA et al., 2013), consequently, from that time, it has already been implemented changes in menus for inclusion of these products.

The most common justification pointed out by the representatives of cities for non-compliance of the Law n.11,947/09 was the "lack of interest of farmers" (38.9\%), and "unsatisfactory hygienicsanitary conditions" (22.2\%). Previous studies have identified as the main difficulty compliance the quality and identity standards, required by federal, state and local laws, which aim to sanitary inspection of food (BELIK \& DOMENE, 2012; RIBEIRO, CERATTI \& BROCH, 2013; BANDONI et al., 2014).

The impossibility of regular and constant supply of food is another major difficulty reported by $11.1 \%$ of the representatives of the surveyed cities. In a nationwide study this same cause represented $21.1 \%$ of the justifications for not performing the purchase (SARAIVA et al., 2013). Other authors pointed out that the difficulty for the purchase, may be due to the presence of large companies of the sector involved in selling food to the government and public institutions (REAL \& SCHNEIDER, 2013), as well as technological limitations and the reduced manpower in small properties (RIBEIRO et al., 2013).

It was also found that the lack of articulation between sectors responsible for school feeding and FF is a factor that affect the implementation of the purchase process. However, these obstacles can be overcome as the purchase of FF become frequent through: the systematic planning of all stages, training of farmers to sell food for school programs, and new forms of financing equipment for better structuring of farmers. Initiatives to structure the production, training farmers for good practices in food handling and labeling, and determination of the validity of FF products have proved to be an effective strategies for meeting the health legislation requirements (CAMPOS et al., 2014).

It was observed that the surveyed cities were buying varied food mostly in natura. Fruit, legume and vegetables (FLV) represented 77.2\% of total food purchases by FF (Table 1). In a study developed by TOYOYOSHI et al. (2013), the fruit or pulp of fruits and vegetables were purchased by $83 \%$ of the cities to be the most available food.

The inclusion of fruit, legume and vegetables (FLV) in school menus is one of the main incentives to promote healthy dietary practices and improves the quality of menus contributing to increased intake of micronutrients and fiber, helping to prevent chronic diseases and obesity in children and adolescents. In addition, nutritionists can innovate in the development of menus including regional preparations which use local fruit, legume and vegetables. Regional preparations tend to be well accepted by the school children, constituting as an important strategy for a healthy feeding. It is affordable and respects the Brazilian culture (CUNHA et al., 2014).

Table 1 also shows the food groups of interest to be purchased by the cities. Although fruit, legume and vegetables account for $77.2 \%$ of food purchased from family farmers, the interest in acquiring these foods in future purchase is lower (69.3\%).

According to the normative resolutions of NSFP, menus must offer at least three servings of fruits and vegetables per week (200g schoolchild ${ }^{-1}$ week $\left.^{-1}\right)$. The interest in acquiring these foods may be due to this requirement, but other hypotheses can be raised, such as: increased supply of these foods by 
Table 1 - Percentage of purchase and purchase interest from family farming for school feeding according to food groups.

\begin{tabular}{lcc}
\hline Group & Purchased food \% (n) & Purchase interest \% (n) \\
\hline Vegetables & $27.3(252)$ & $15.0(70)$ \\
Fruit / fruit pulp & $26.8(246)$ & $30.9(144)$ \\
Legumes & $23.1(213)$ & $23.4(109)$ \\
Cereals, tubersand roots & $16.6(153)$ & $16.3(76)$ \\
Juice & $1.6(15)$ & $1.7(8)$ \\
Leguminous & $1.6(15)$ & $3.0(14)$ \\
Meat and Eggs & $1.0(9)$ & $4.7(22)$ \\
Honey & $0.7(7)$ & $0.6(3)$ \\
Sweets & $0.6(6)$ & $2.4(11)$ \\
Formulated & $0.3(3)$ & $0.0(0)$ \\
Other & $0.3(3)$ & $1.9(9)$ \\
\hline
\end{tabular}

*Nutritionist could choose more than one justification.

family farmers, FLV is easier to purchase compared to products of animal origin, and the importance of FLV in promoting health due to the presence of vitamins, minerals, fiber and bioactive compounds at high levels. It can also be observed that cities have no interest in purchasing powdered dairy food in the future. The acquisition of these products is restricted by the Brazilian government (BRAZIL, 2013), a factor that may have stimulated this result.

The preference for the purchase of organic or agro ecological food rather than those from conventional cultivation was reported by only $6.5 \%$ of the cities studied, although the resolution n. 26 (BRAZIL, 2013) indicate this criteria as a priority for the purchase of FF. A study in rural areas of the cities of the Rio Grande do Sul state, showed that only $20.58 \%$ of the 102 cities surveyed have stated acquiring organic food from FF (SANTOS et al., 2014). It should be noted that there are some difficulties to acquire the organic/agroecological food for the school feeding programs as: the mismatch between supply and demand, the small range of food and the absence of certification (SILVERIO \& SOUSA, 2014).

One of Brazilian NSFP objectives is to contribute to formation of healthy eating habits of school children, through nutrition education actions (BRAZIL, 2013). However, only $42.9 \%$ of the studied cities reported developing these actions, and of those who performed $85 \%$ reported that they had record these activities.

Of the cities that reported purchasing products of the FF $(n=62), 28$ sent menus planned before and after the beginning of the acquisition process, the responsible of other cities forwarded the menus only after the acquisition, in other words, current menus (58) with the following reasons: there is no previous menu; there was no menu change and the nutritionist (responsible by the school feeding program) had changed. All menus were analyzed qualitatively through QISFM.

The graphs in figure 1 show that the food groups that appear more frequently in the school feeding menus were cereals/tubers and meats/ eggs. Less frequently it was observed the diary group. This may have occurred because with the beginning of purchases from FF, cities may have opted for providing a full meal instead of snacks. The cities often inform acquiring fruit, legume and vegetables of $\mathrm{FF}$, but the appearance of fruit, for example, was lower in the current menu, after the start of the FF purchases.

Table 2 shows the distribution of cities according to the categorization of menus taking into account the QISFM. It is possible to observe the progression of most cities when they started the FF purchases. For example, only $10 \%$ of the cities had classified menus as great before purchasing of $\mathrm{FF}$, and after the purchase, this category represented $22.4 \%$ of the cities. Moreover, it can be seen that prior to purchase of family farming $51.7 \%$ of the cities had menus in unsatisfactory conditions (classified as poor and bad) according to QISFM. However, after the acquisition this percentage decreased to $36.2 \%$.

The QISFM scores were compared before: $2.44(0.84)$ and after: $2.88(0.83)$ the beginning of the purchase process from family farmers by cities, characterizing significant increase $(\mathrm{P}<0.001 ; \mathrm{t}=-3.67)$ of this score. This increase is the result of improving the quality of menus by including FF products and other factors that may have been guided by the publication of the law 11,947 . 


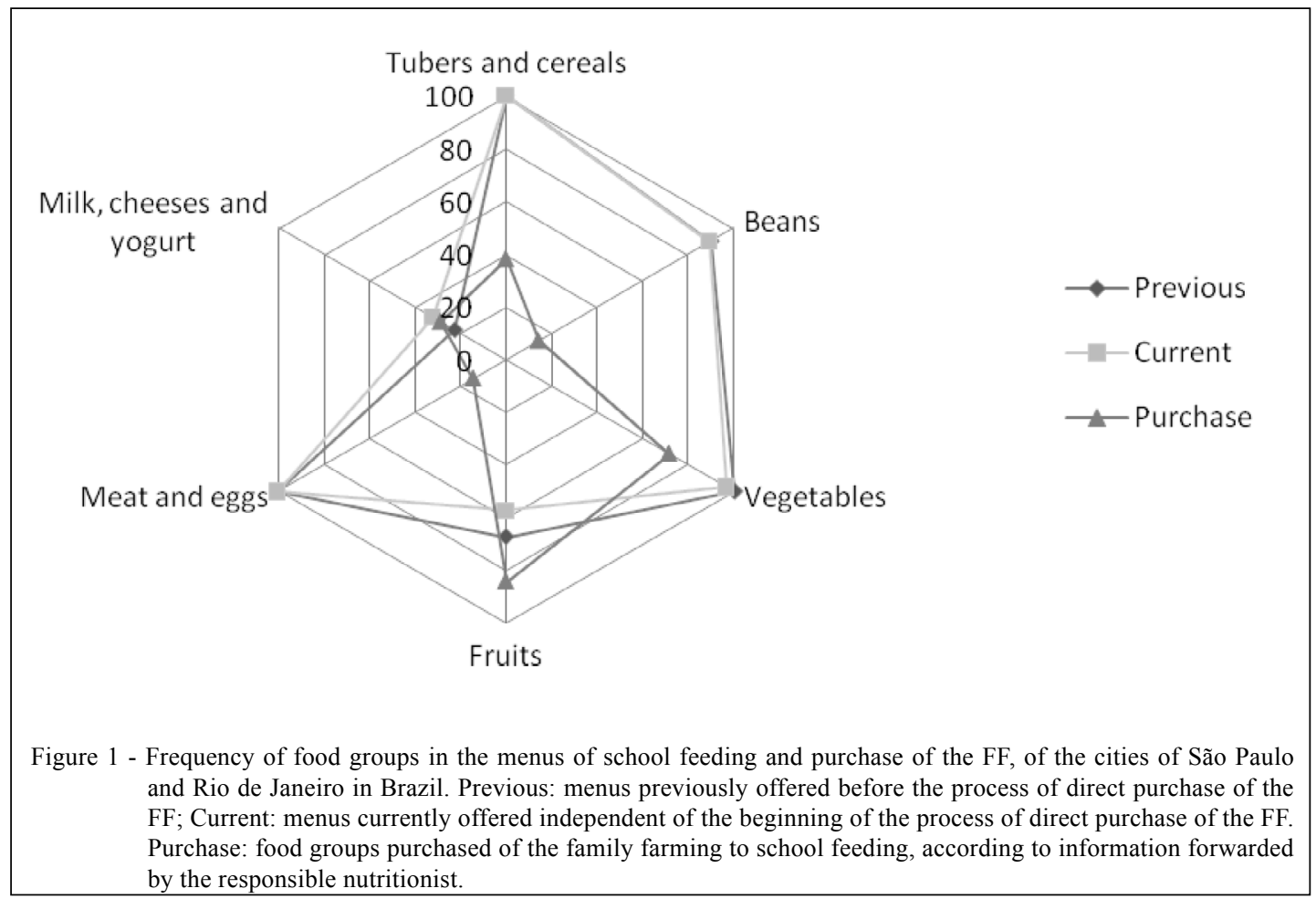

In a study conducted in two cities of São Paulo that used the QISFM, the authors identified average scores of 2.9 and 4.8 , and also reported that in the city with the lowest average value occurred low frequency of fruit and dairy products, and high incidence of smoke-dried meats (eg. ham and sausage). But in the other city, the supply of different groups of food was regular, however, it was observed that the purchase of family farming alone did not guarantee a better quality of the offered menu (BELIK \& DOMENE, 2012).

Although the evaluation of the quality of the menus using the QISFM is an important measure for the control of food offered to school children, it must be noted that in the school environment some adjustments of menus often occurs due to the lack of ingredients or even the inability of the cooks in performing preparations. ISSA et al. (2014) showed that $79 \%$ of planned menus for school feeding were changed, and that, the median of energy consumption and all nutrients was lower than the minimum values established by Brazilian government for the two age groups (6 to 10 and 11 to 15 years old).

TEO \& MONTEIRO (2012) suggest that the planning of the menus of NSFP should be performed taking into account different dimensions, such as the presence of basic and healthy food, belonging to local food culture, and from the family farm. They also recommend the exclusion of ultraprocessed food, and the minimum supply of one fruit and vegetables for each meal. In this perspective the QISFM methodology takes into consideration various aspects previously mentioned, that can facilitate nutritionists, the School Feeding Board (Conselho de Alimentação Escolar - CAE in Portuguese) and managers of school meals in assessing the nutritional quality of the menus being offered to schoolchildren.

Table 2 - Distribution of cities according to the categorization of menus taking into account the Quality Index for School Feeding Menu (QISFM).

\begin{tabular}{lcc}
\hline & & \\
& Previous buying from & Current buying from \\
& FF n (\%) & FF n (\%) \\
\hline Bad & $10(34.5)$ & $8(138)$ \\
Poor & $5(17.2)$ & $13(22.4)$ \\
Regular & $6(20.7)$ & $11(18.9)$ \\
Good & $5(17.2)$ & $13(22.4)$ \\
Great & $3(10.3)$ & $13(22.4)$ \\
Total & $29(100)$ & $58(100)$ \\
\hline
\end{tabular}

FF- Family Farming.

Ciência Rural, v.45, n.12, dez, 2015. 


\section{CONCLUSION}

It can be concluded that $92.7 \%$ of the cities studied discuss about the FF buying process for school feeding and $74.1 \%$ actually do purchase. The years 2010 and 2011 were identified as initial for the purchase of FF products for school feeding in the most of the studied cities. The lack of interest of farmers was the main difficulty reported by the responsible of the cities for the realization of purchases of FF, but other causes, such as the sanitary inadequacy of the food was also cited as an important limitation

Family farming purchase has improved the quality of the menus offered to school children, according to the scores of QISFM, thus contributing to the offering of healthier meals for school children. However, it was observed that the supply of fruit on menus was less frequent after the start of the FF purchases, although nutritionists have declared interest in the acquisition of fruit, legume and vegetables in $69 \%$ of cities studied.

The importance of respecting the healthy food cultures, through the purchasing of FF production, encourages the communities self-reliance, boosts the local economy, and provides sustainable development by stimulating the consumption of fresh and in natura food. It contributes significantly to the development of healthy eating habits of schoolchildren, and consequently, to change the current Brazilian panorama of increasing obesity.

\section{BIOETHICS AND BIOSSECURITY COMMITTEE APPROVAL}

This study was approved by the Ethics Committee of the Universidade Federal de São Paulo (Unifesp) research, through the Platform Brazil, under the protocol n. 256 967, 2013.

\section{REFERENCES}

BANDONI, D.H. et al. Health regulation challenges for safety of food acquired from family farms for school meals. Revista Visa em debate, v.2, n.4, p.107-114, 2014. Available from: <http:// periodicos.fiocruz.br/pt-br/publicacao/16159>. Accessed: Apr. 04, 2014. doi: 10.3395/VD.V2I4.473.

BELIK, W.; DOMENE, S.M.A. Combined food school programs experiences and local development in São Paulo, Brazil. Agroalimentaria, v.18, n.34, p. 57-72, 2012. Available from: $<$ http://erevistas.saber.ula.ve/index.php/agroalimentaria/article/ view/4099>. Accessed: Oct. 08, 2014.

BRAZIL. Lei n. 11.947, de 16 de junho de 2009. Dispõe sobre o atendimento da alimentação escolar e do Programa Dinheiro Direto na Escola aos alunos da educação básica. Diário Oficial da União, Poder Legislativo, Brasília, DF, 17 jun. 2009a.
BRAZIL. Resolução n. 38, 16 de julho de 2009. Dispõe sobre o atendimento da alimentação escolar aos alunos da educação básica no âmbito do Programa Nacional de Alimentação Escolar (PNAE). Diário Oficial da União, Poder legislativo, Brasília, DF, 16 jul. 2009 b.

BRAZIL. Resolução n.26, de 17 de junho de 2013. Dispõe sobre o atendimento da alimentação escolar aos alunos da educação básica no âmbito do Programa Nacional de Alimentação Escolar (PNAE). Diário Oficial da União, Poder legislativo, Brasília, DF, 18 jun. 2013.

CAMPOS, M.R.H. et al. Family farm food production for school meals: Health Regulation challenges. Vigilância Sanitária em Debate, v.2, n.4, p.102-106, 2014. Available from: <https:// visaemdebate.incqs.fiocruz.br/index.php/visaemdebate/article/ view/418/171>. Accessed: Apr. 04, 2015. doi: 10.3395/VD.V2i4.418.

CUNHA, D. T. et al. Preparações regionais no Programa Nacional de Alimentação Escolar: aceitabilidade e composição nutricional. Revista de Nutrição, v.27, n.4, p. 423-434, 2014. Available from: $<$ http://www.scielo.br/scielo.php?script=sci_arttext\&pid=S141552732014000400423\&lng=en\&nrm=iso >. Accessed: Apr. 07, 2015. doi: 10.1590/1415-52732014000400004.

DOMENE, S.M.A. et al. A alimentação na escola: uma avaliação qualitativa. In: SAWAYA, A.L. (Org.). Desnutrição, pobreza e sofrimento psíquico. São Paulo: Edusp, 2011. 360p.

FNDE (FUNDO NACIONAL DE DESENVOLVIMENTO DA EDUCAÇÃO). Histórico do programa Nacional de Alimentação Escolar (PNAE). Brasília. Available from: < http://www.fnde.gov. br/index.php/ae-historico>. Accessed: Apr. 04, 2014.

ISSA, R.C. et al. Alimentação escolar: planejamento, produção, distribuição e adequação. Revista Panamericana de Salud Publica, v.35, n.2, p.96-103, 2014. Available from: <http:// www.scielosp.org/pdf/rpsp/v35n2/a03v35n2.pdf>. Accessed: Apr. 03, 2015.

MATIHARA, C.H. et al. Valor nutricional da merenda escolar e sua aceitabilidade. Saúde e Pesquisa, v.3, n.1, p.71-77, 2010. Available from: <http://periodicos.unicesumar.edu.br/index.php/ saudpesq/article/view/1230>. Accessed: Oct. 05, 2014.

MINISTÉRIO DO DESENVOLVIMENTO AGRÁRIO (MDA). Alimentação escolar. Brasília. Available from: $<$ http://www.mda. gov.br>. Accessed: Sept. 10, 2014.

NEITZKE, L. et al. Nutritional adequacy of school feeding in rural municipality - Espírito Santo, Brazil. Nutrire, v.37, n.1, p.1-12, 2012. Available from: <http://dx.doi.org/10.4322/ nutrire.2012.001>. Accessed: Oct. 01, 2014. doi: 0.4322/ nutrire.2012.001.

REAL, L.C.V.; SCHNEIDER, S. O uso de programas públicos de alimentação na reaproximação do pequeno produtor com o consumidor: o caso do programa de alimentação escolar. Estudo e debate, v.18, n.2, p.57-79, 2013. Available from: $<\mathrm{http}: / /$ univates. $\mathrm{br} /$ revistas/index.php/estudoedebate/article/viewFile/125/200>. Accessed: Sept. 29, 2014.

RIBEIRO, A.L.P. et al. Programa Nacional de Alimentação Escolar (PNAE) e a participação da agricultura familiar em municípios do Rio Grande do Sul. Revista Gestão da Agricultura Familiar em Municípios do Rio Grande do Sul, v.1, n.1, p.36-49, 2013. 
Available from: $<$ http://revistaeletronica.unicruz.edu.br/index.php/ GEDECON/article/view/282>. Accessed: Apr. 04, 2015.

SANTOS, F. et al. Avaliação da inserção de alimentos orgânicos provenientes da agricultura familiar na alimentação escolar, em municípios dos territórios rurais do Rio Grande do Sul, Brasil. Ciência e Saúde Coletiva, v.19, n.5, p.1439-1436, 2014. Available from: <http://dx.doi.org/10.1590/141381232014195.14982013>. Accessed: Apr. 04, 2015. doi: 10.1590/1413-81232014195.14982013.

SARAIVA, E.B. et al. Panorama da compra de alimentos da agricultura familiar para o Programa Nacional de Alimentação Escolar. Ciência e Saúde Coletiva, v.18, n.4, p.927-936, 2013. Available from: <http://dx.doi.org/10.1590/S141381232013000400004>. Accessed: Sept. 28, 2014. doi: 10.1590/ S1413-81232013000400004.

SILVA, M.M.D.C.; GREGÓRIO, E.L. Avaliação da composição nutricional de cardápios da alimentação escolar das escolas da rede municipal de Taquaraçu de Minas - MG. HU Revista, v.37, n.3, p.387-394, 2012. Available from: <http://hurevista.ufjf.emnuvens. com.br/hurevista/article/view/1734>. Accessed: Apr. 04, 2015.

SILVERIO, G.A.; SOUSA, A.A. Organic foods from family farms in the National School Food Program: perspectives of social actors from Santa Catarina, Brazil. Revista de Nutrição, v.21, n.3, p.289-300, 2014. Available from: <http://dx.doi. org/10.1590/1415-52732014000300003>. Accessed: Apr. 04, 2014. doi: $10.1590 / 1415-52732014000300003$.

SOUZA, A.L.C.; MAMEDE, M.E.O. Estudo sensorial e nutricional da merenda escolar de Lauro de Freitas - BA. Revista do Instituto Adolfo Lutz, v.69, n.2, p.255-260, 2010. Available from: <https:// ri.ufs.br/bitstream/123456789/601/1/EstudoNutricionalMerenda. pdf>. Accessed: Mar. 29, 2015.

VILLAR, B.S. et al. Situação dos municípios do estado de São Paulo com relação à compra direta de produtos da agricultura familiar para o Programa Nacional de Alimentação Escolar (PNAE). Revista Brasileira de Epidemiologia, v.16, n.1, p.233-236, 2013. Available from: <http://dx.doi.org/10.1590/S1415-790X2013000100021>. Accessed: Oct. 28, 2014. doi: 10.1590/S1415-790X2013000100021.

TEO, C.R.P.A.; MONTEIRO, C.A. Marco legal do Programa Nacional de Alimentação Escolar: uma releitura para alinhar propósitos e praticas na aquisição de alimentos. Revista de Nutrição, v.25, n.5, p.657-668, 2014. Available from: <http:// dx.doi.org/10.1590/S1415-52732012000500010>. Accessed: Apr. 02, 2015. doi: 10.1590/S1415-52732012000500010.

TOYOYOSHI, J.Y. et al. Avaliação da aquisição de gêneros alimentícios provenientes da agricultura familiar para alimentação escolar. O mundo da saúde, v.37, n.3, p.329-335, 2013. Available from: <http:// saocamilo-sp.br/pdf/mundo_saude/106/1829.pdfhttp:/saocamilo-sp.br/ pdf/mundo_saude/106/1829.pdf $>$. Accessed: Sept. 28, 2014. 